\title{
Absence of left circumflex coronary artery: case report and minireview
}

Brak gałęzi okalającej lewej tętnicy wieńcowej - opis przypadku i przegląd piśmiennictwa

\author{
Suleyman Ercan'1 Ibrahim Sari², Orhan Ozer ${ }^{1}$, Murat Yuce ${ }^{1}$, Vedat Davutoglu ${ }^{1}$ \\ ${ }^{1}$ Department of Cardiology, Gaziantep University, Turkey \\ 2Department of Cardiology, Marmara University, Istanbul, Turkey
}

Postep Kardiol Inter 2012; 8, 4 (30): 342-346

DOI: 10.5114/pwki.2012.31917

\begin{abstract}
Absence of the left circumflex coronary artery (LCX) is a very rare coronary anomaly. The anomaly has been reported in only $0.003 \%$ of all patients who underwent routine coronary angiography. Although rare, the failure to visualize a coronary artery in its expected anatomical location might cause life-threatening complications such as total occlusion with acute coronary syndromes. In the present paper, we report a patient with absent LCX and discuss the previously reported cases in terms of diagnostic and clinical importance, association with atherosclerosis and other anomalies. We searched Medline (www.ncbi.nlm.nih.gov) for cases of absent LCX and found that so far absence of LCX has been reported 27 times and in 32 cases. Here in this case report and minireview we discuss the characteristics of the present case and previous 32 cases with absence of LCX. The majority of the patients were over 30 years old at the time of diagnosis and the condition is more common in females. Although absence of LCX is generally considered as a benign entity, it might be atherosclerotic and can cause acute coronary syndromes including myocardial infarction and be associated with other anomalies. Proper diagnosis of the absence of LCX is very important because it can be misinterpreted as a totally occluded LCX. In subjects with absent LCX, infarction in the superdominant RCA might be more dangerous. It is more common in females and although conventional coronary angiography is the most widely used diagnostic modality, multidetector computed tomography might also be helpful.
\end{abstract}

Key words: absent, left circumflex coronary artery

\section{Streszczenie}

Brak gałęzi okalającej lewej tętnicy wieńcowej (left circumflex artery - LCX) jest bardzo rzadką anomalią wieńcową. Obserwowano ją u 0,003\% wszystkich pacjentów poddawanych rutynowej koronarografii. Nieuwidocznienie tętnicy wieńcowej w jej typowej lokalizacji anatomicznej może, chociaż rzadko, powodować zagrażające życiu powikłania, takie jak całkowita niedrożność tętnicy z ostrym zespołem wieńcowym. W poniższej pracy przedstawiono pacjenta z brakiem LCX. Ponadto opisano wcześniej opublikowane przypadki tej anomalii w odniesieniu do ich znaczenia diagnostycznego i klinicznego oraz związku z miażdżycą i innymi anomaliami. W tym celu autorzy przeszukali bazę Medline (www.ncbi.nlm.nih.gov) pod kątem hasła „brak LCX” i stwierdzili, że dotychczas anomalię tę opisano 27 razy w 32 przypadkach. Na poniższym przykładzie, w połączeniu z wcześniejszymi danymi z piśmiennictwa, przedstawiono charakterystykę opisanych 32 chorych oraz 1 nowego z brakiem LCX. Większość pacjentów w momencie rozpoznania miała więcej niż 30 lat; anomalia ta częściej występuje u kobiet. Chociaż brak LCX jest raczej uważany za anomalię łagodną, to może ona wiązać się z miażdżycą i spowodować ostry zespół wieńcowy, w tym zawał serca, lub być skojarzona z innymi anomaliami. Ponieważ brak LCX może być niepoprawnie zinterpretowany jako całkowita niedrożność tętnicy, niezmiernie ważne jest właściwe rozpoznanie. Zawały serca obejmujące superdominującą prawą tętnicę wieńcową u chorych z brakiem LCX mogą być bardziej niebezpieczne. Mimo że tradycyjna koronarografia jest najczęściej stosowaną metodą diagnostyczną, pomocna może być także wielorzędowa tomografia komputerowa.

Słowa kluczowe: brak, gałąź okalająca lewej tętnicy wieńcowej

\section{Introduction}

Absence of the left circumflex coronary artery (LCX) is a very rare coronary anomaly. The anomaly has been re- ported in only $0.003 \%$ of all patients who underwent routine coronary angiography [1]. Although rare, the failure to visualize a coronary artery in its expected anatomical 
location might cause life-threatening complications such as total occlusion with acute coronary syndromes.

In the present paper, we report a patient with absent LCX and discuss the previously reported cases in terms of diagnostic and clinical importance, association with atherosclerosis and other anomalies.

\section{Case report}

A 48-year-old woman was admitted to our hospital with atypical precordial chest pain for 2 years. Because
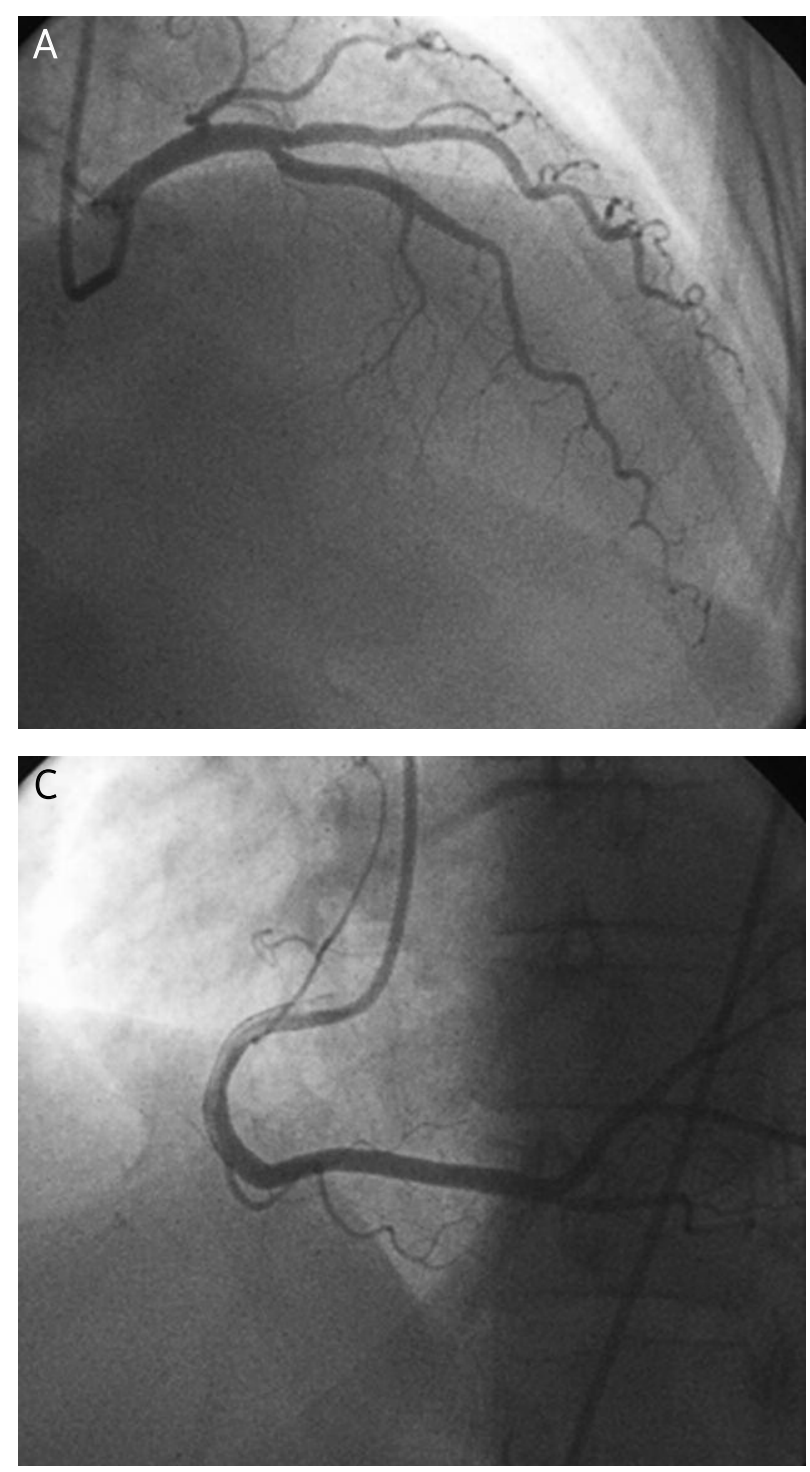

the treadmill exercise stress test was positive, she underwent coronary angiography. On coronary angiography, the left coronary arteriogram showed only one artery arising from the left sinus of Valsalva and continuing as a single left anterior descending coronary artery (LAD) which gave off a large diagonal branch for the left ventricular lateral wall (dual LAD) (Fig. 1). No LCX was seen with a left injection after several different views with repeated coronary angiograms. Then selective right coronary angiography revealed a superdominant right coronary artery (RCA)
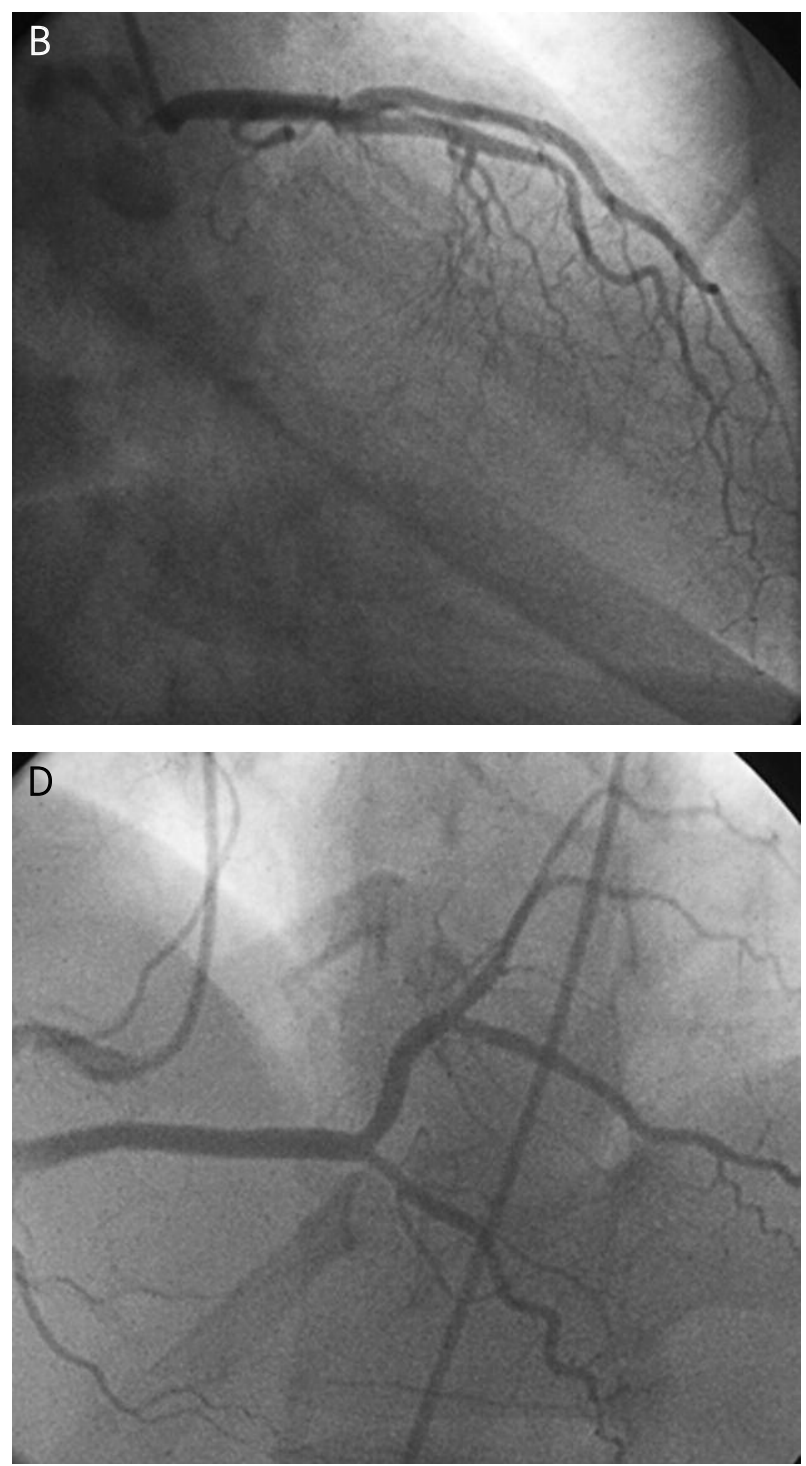

Fig. 1 A-D. Coronary angiography of the patient demonstrating only one artery arising from the left sinus of Valsalva and continuing as a single left anterior descending coronary artery (LAD) which gave off a large diagonal branch for the left ventricular lateral wall (dual LAD). Selective right coronary angiography reveals a superdominant right coronary artery which crosses the crux of the heart and ascends into the atrioventricular groove, perfusing the posterolateral and lateral walls of the left ventricle

Ryc. 1 A-D. Koronarografia pacjenta przedstawiająca obecność tylko jednej tętnicy odchodzacej od lewej zatoki Valsalvy o przebiegu gatęzi przedniej zstępującej (left anterior descending - LAD) oddającej duża gałąź diagonalna zaopatrująca ścianę boczną serca (podwójna LAD). Selektywna angiografia prawej tętnicy wieńcowej ujawnia jej superdominujacy charakter z przechodzeniem tętnicy za crux cordis i wstępowaniem do bruzdy przedsionkowo-komorowej, co umożliwia perfuzję ściany bocznej i tylno-bocznej lewej komory 
which crossed the crux of the heart and ascended into the atrioventricular groove, perfusing the posterolateral and lateral walls of the left ventricle (Fig. 1). There were no critical lesions in the coronary arteries. An aortic root arteriography was performed to reveal whether there was evidence of the LCX from any separate origin, but it verified the absence of LCX. Because the treadmill exercise stress test was positive, we performed dobutamine stress echocardiographic examination to prove/exclude ischaemia and it was completely normal.

\section{Discussion}

Like double RCA, absence of the LCX is very rare in the literature, with a frequency of $0.003 \%$ in all patients who underwent routine coronary angiography [1-5]. Absence of the LCX is usually associated with a large "super-dominant" RCA whose well-developed postero-lateral branches cross the crux of the heart ascending to the left atrioventricular groove and perfuse the zone extending to the LCX territories (Fig. 1). Moreover, the LAD's well-developed branches (like the present case) or dual LAD may contribute blood supply to the absent LCX territories. These compensating mechanisms prevent myocardial ischaemia and therefore this anomaly is generally accepted as a benign condition unless an atherosclerotic process is superimposed.

We searched MEDLINE (www.ncbi.nlm.nih.gov) for cases of absent LCX and found that so far absence of LCX has been reported 27 times and in 32 cases [6-31]. Here in this case report and minireview we discuss the characteristics of the present case and previous 32 cases with absence of LCX (Table 1). The majority of the patients were over

Table 1. Clinical characteristics of the cases with absent LCX

Tabela 1. Charakterystyka kliniczna pacjentów z brakiem LCX

\begin{tabular}{|c|c|c|c|c|c|c|c|c|}
\hline Author & $\begin{array}{l}\text { Date published/ } \\
\text { available online }\end{array}$ & $\begin{array}{l}\text { Number } \\
\text { of cases }\end{array}$ & $\begin{array}{l}\text { Coronary } \\
\text { atherosclerosis }\end{array}$ & Sex & $\begin{array}{c}\text { Age at } \\
\text { diagnosis }\end{array}$ & $\begin{array}{l}\text { Associated } \\
\text { anomaly }\end{array}$ & $\begin{array}{l}\text { Diagnostic } \\
\text { tool }\end{array}$ & Country \\
\hline Barresi & 1973 & 2 & $\mathrm{~N}$ & $?$ & $?$ & $\mathrm{~N}$ & CA & USA \\
\hline Mievis & 1979 & 1 & N & M & 31 & N & CA & France \\
\hline Bestetti & 1985 & 1 & N & $\mathrm{F}$ & 12 & DCMP & Autopsie & Brazil \\
\hline Sagkan & 1994 & 1 & $?$ & $?$ & $?$ & $?$ & CA & Turkey \\
\hline Ilia & 1994 & 1 & $?$ & $?$ & $?$ & $?$ & & Israel \\
\hline Baruah & 1998 & 1 & $?$ & $?$ & $?$ & $?$ & CA & India \\
\hline Pillai & 2000 & 4 & $?$ & $?$ & $?$ & $?$ & CA & Northern Ireland \\
\hline Uyan & 2000 & 1 & $?$ & $?$ & $?$ & $?$ & CA & Turkey \\
\hline Itoi & 2001 & 1 & N & $F$ & 13 & $\mathrm{~N}$ & CA & Japan \\
\hline Lin & 2003 & 1 & N & $\mathrm{F}$ & 44 & N & CA & Taiwan \\
\hline Sagkan & 2003 & 1 & N & M & 61 & N & CA & Turkey \\
\hline Hashimoto & 2004 & 1 & Y & $M$ & 49 & N & CA & Japan \\
\hline Badak & 2004 & 1 & N & $F$ & 53 & $N$ & CA & Turkey \\
\hline Vijayvergiya & 2005 & 1 & N & $F$ & 40 & N & CA & India \\
\hline Doven & 2006 & 1 & N & $M$ & 67 & $\mathrm{~N}$ & CA & Turkey \\
\hline Sato & 2006 & 1 & $Y$ & $M$ & 62 & N & $C A+M D C T$ & Japan \\
\hline Liu & 2007 & 1 & N & $F$ & 17 & N & MDCT & Taiwan \\
\hline Srinivasan & 2008 & 1 & $?$ & $?$ & 455 & $?$ & MDCT & India \\
\hline Mittal & 2008 & 1 & $Y$ & $F$ & 57 & $N$ & CA & India \\
\hline Ali & 2009 & 2 & $\mathrm{Y}, \mathrm{N}$ & $M, M$ & 40,39 & N & CA & Pakistan \\
\hline Yoon & 2009 & 1 & N & M & 48 & $\mathrm{MB}$ & CA & South Korea \\
\hline Yameen & 2010 & 1 & $\mathrm{~N}$ & $F$ & 55 & $\mathrm{~N}$ & MDCT & India \\
\hline Baskurt & 2010 & 1 & N & $\mathrm{F}$ & 55 & N & $C A+M D C T$ & Turkey \\
\hline Coppi & 2011 & 1 & N & $\mathrm{F}$ & 38 & LVA & CA & Italy \\
\hline Majid & 2011 & 1 & N & $F$ & 55 & $N$ & MDCT & India \\
\hline Bildirici & 2011 & 1 & $Y$ & $\mathrm{~F}$ & 67 & Dual LAD & CA & Turkey \\
\hline Guo & 2012 & 1 & $Y$ & $M$ & 52 & $N$ & $C A+M D C T$ & China \\
\hline
\end{tabular}

$L C X$ - left circumflex coronary artery, $Y$-yes, $N$-no, $M$ - male, F-female, MB - myocardial bridge, LAD - left anterior descending artery, CA - coronary angiography, MDCT - multidetector computed tomography 
30 years old at the time of diagnosis and the condition is more common in females.

Hashimoto et al. reported absence of LCX associated with acute anterior myocardial infarction [6]. Percutaneous coronary intervention has been successfully performed to complete occlusion of the left main trunk. If patients undergo emergency coronary angiography, coronary arteries should be quickly and correctly evaluated in order to apply the best treatment modality. An unusually long left main coronary artery or super-dominant right coronary artery may be a clue for absence of LCX. Sato et al. reported an RCA critical lesion with absence of LCX [12]. This condition should be evaluated as equivalent to two-vessel disease including both the RCA and LCX.

Cases of absence of LCX have been sporadically reported during routine coronary angiography. Bestetti et al. found absence of LCX with idiopathic dilated cardiomyopathy in autopsy [15]. These conditions may be accepted to co-exist by chance. On the other hand, Coppi et al. speculated that thoracic large vessel anomalies might be associated with this anomaly [18]. Some authors suggest that multidetector computed tomography should be used in diagnosis of this rare coronary anomaly. Liu et al. reported the case of a 17-year-old girl in whom the clinical diagnosis was absence of LCX by multidetector computed tomography [9]. It may be especially an alternative imaging modality to coronary angiography if patients are young or have atypical chest pain. It is also a safe, non-invasive, cost-effective and fast imaging technique which enables detailed evaluation of coronary arteries.

In conclusion, although absence of LCX is generally considered as a benign entity, it might be atherosclerotic and can cause acute coronary syndromes including myocardial infarction and be associated with other anomalies. Proper diagnosis of absence of LCX is very important because it can be misinterpreted as a totally occluded LCX. In subjects with absent LCX, infarction in the superdominant RCA might be more dangerous. It is more common in females and although conventional coronary angiography is the most widely used diagnostic modality, multidetector computed tomography might also be helpful.

\section{References}

1. Yamanaka O, Hobbs RE. Coronary artery anomalies in 126,595 patients undergoing coronary arteriography. Cathet Cardiovasc Diagn 1990; 21: 28-30.

2. Sari I, Kizilkan N, Sucu M, et al. Double right coronary artery: report of two cases and review of the literature. Int J Cardiol 2008; 130: e74-e77.

3. Sari I, Davutoglu V, Aksoy M. The correct number of double right coronary artery reported in the literature. Int J Cardiol 2008; 130: 283-284.

4. Soydinc S, Sari I, Davutoglu V. The dilemma in diagnosing double right coronary artery: contribution of multidetector computed tomography. Int J Cardiol 2008; 126: 132-133.
5. Sari I, Uslu N, Gorgulu S, et al. Inferior myocardial infarction and extensive atherosclerosis in a patient with double right coronary artery. Int J Cardiol 2006; 111: 321-323.

6. Hashimoto N, Nagashima J, Miyazu O, et al. Congenital absence of the left circumflex coronary artery associated with acute myocardial infarction: a case report. Circ J 2004; 68: 91-93.

7. Bildirici U, Kılıç T, Ural D, et al. Combined congenital coronary artery anomaly: dual left anterior descending coronary artery and absence of left circumflex artery. Anadolu Kardiyol Derg 2011; 11: 180-181.

8. Baskurt M, Okcun B, Caglar IM, et al. Congenital absence of the left circumflex coronary artery and an unusually dominant course of the right coronary artery. Cardiovasc J Afr 2010; 21: 286-288.

9. Liu CY, Juan CW, Pai YL, Tseng YZ. Congenital left circumflex coronary artery atresia detected by 64-slice computed tomography: a case report. Kaohsiung J Med Sci 2007; 23: 313-317.

10. Yoon YK, Rha SW, Na JO, et al. Congenital absence of left circumflex coronary artery presented with vasospastic angina and myocardial bridge in single left coronary artery. Int J Cardiol 2009; 131: e108-e111.

11. Doven O, Yurtda M, Cicek D, Ozcan IT. Congenital absence of left circumflex coronary artery with superdominant right coronary artery. Anadolu Kardiyol Derg 2006; 6: 208-209.

12. Sato $\mathrm{Y}$, Matsumoto N, Ichikawa M, et al. MDCT detection of congenital absence of the left circumflex artery associated with atherosclerotic coronary artery disease. Int J Cardiol 2006; 113: 408-409.

13. Badak O, Akdeniz B, Ozpelit E, Güneri S. Coronary artery abnormality: congenital absence of left circumflex coronary artery. Anadolu Kardiyol Derg 2004; 4: 194.

14. Lin TC, Lee WS, Kong CW, Chan WL. Congenital absence of the left circumflex coronary artery. Jpn Heart J 2003; 44: 1015-1020.

15. Bestetti RB, Costa RB, Oliveira JS, et al. Congenital absence of the circumflex coronary artery associated with dilated cardiomyopathy. Int J Cardiol 1985; 8: 331-335.

16. Mievis E, Bopp P, Righetti A. Congenital absence of the circumflex artery. Association with an infarction without coronary disease. Arch Mal Coeur Vaiss 1979; 72: 1155-1159.

17. Barresi V, Susmano A, Colandrea MA, et al. Congenital absence of the circumflex coronary artery. Clinical and cinearteriographic observations. Am Heart J 1973; 86: 811-816.

18. Coppi F, Roversi S, Giuliani E, et al. Circumflex coronary artery agenesis associated with thoracic great vessels anomalies. J Thorac Imaging 2011; 26: W9-W11.

19. Baruah DK, Babu PR, Prasad S. Absent left circumflex coronary artery. Indian Heart J 1998; 50: 335-336.

20. Vijayvergiya R, Kumar Jaswal R. Anomalous left anterior descending, absent circumflex and unusual dominant course of right coronary artery: a case report. Int J Cardiol 2005; 102: 147-148.

21. Itoi T, Oka T, Hamaoka K. Abnormal coronary flow reserve in a 13-year-old girl with an absent left circumflex coronary artery. Pediatr Cardiol 2001; 22: 165-166.

22. Majid $Y$, Warade $M$, Sinha J, et al. Superdominant right coronary artery with absent left circumflex artery. Biomed Imaging Interv J 2011; 7: e2.

23. Ali FS, Khan SA, Tai JM, et al. Congenital absence of left circumflex artery with a dominant right coronary artery. BMJ Case Rep 2009; 2009. pii: bcr08.2008.0772.

24. Ilia R, Jafari J, Weinstein JM, Battler A. Absent left circumflex coronary artery. Cathet Cardiovasc Diagn 1994; 32: 349-350. 
25. Pillai SB, Khan MM, Diamond A, McKeown PP. The prevalence and types of coronary artery anomalies in Northern Ireland. Ulster Med J 2000; 69: 19-22.

26. Mittal SR, Maheshwari M. Absent left circumflex artery and unusual dominant right coronary artery. J Assoc Physicians India 2008; 56: 711.

27. Sagkan O, Ornek E, Yeșildağ O. Left circumflex coronary artery arising as a terminal extension of right coronary artery. A case report. Angiology 1994; 45: 405-8.

28. Uyan C, Altinmakas S, Pektaș O. Left circumflex coronary artery arising as a terminal extension of the right coronary artery. Acta Cardiol 2000; 55: 101-102.

29. Sagkan O, Yazici M, Demircan S. Left circumflex coronary artery arising as a terminal extension of the right coronary artery. Heart 2003; 89: 286.

30. Srinivasan KG, Gaikwad A, Kannan BR, et al. Congenital coronary artery anomalies: diagnosis with 64 slice multidetector row computed tomography coronary angiography: a single-centre study. J Med Imaging Radiat Oncol 2008; 52: 148-154.

31. Guo J, Xu M. Congenital absence of the left circumflex artery associated with inferior myocardial infarction. Intern Med 2012; 51: 71-74. 